Citation: Journal of Asian Earth Sciences, vol.30(5-6); 696-705p.

\title{
Do manganese nodules grow or dissolve after burial? Results from the Central Indian Ocean Basin
}

\author{
J. N. Pattan* and G.Parthiban \\ National Institute of Oceanography \\ Dona Paula, 403 004, Goa, India.
}

\begin{abstract}
Fifty buried manganese nodules at different depth intervals were recovered in 12 sediment cores from the Central Indian Ocean Basin (CIOB). A maximum of 15 buried nodules were encountered in one sediment core (AAS-22/GC-07) and the deepest nodule was recovered at $5.50 \mathrm{~m}$ below seafloor in core AAS-04/GC-5A. Approximately $80 \%$ of the buried nodules are small in size ( $\sim 2 \mathrm{~cm}$ diameter) in contrast to the Atlantic Ocean and Peru Basin (Pacific Ocean) where the majority of the buried nodules are large, $\sim 8 \mathrm{~cm}$ and $>6 \mathrm{~cm}$ respectively. Buried nodule size decreases with core depth and this distribution appears to be similar to the phenomenon of "Brazil Nut Effect". Buried nodules exhibit both smooth and rough surface textures and are ellipsoidal, elongated, rounded, sub rounded, irregular and polynucleated. Buried nodules from siliceous ooze are enriched in $\mathrm{Mn}, \mathrm{Cu}, \mathrm{Ni}, \mathrm{Zn}, \mathrm{Mo}, \mathrm{Ga}, \mathrm{V}$ and $\mathrm{Rb}$ whereas those from red clay are enriched in Fe, Co, Ti, U, Th, Y, Cr, Nb and Rare Earth Elements (REE). Buried nodules from siliceous ooze suggest their formation under hydrogenetic, early digenetic and diagenetic processes whereas those from red clay are of hydrogenetic origin.

REE are enriched more than 1.5 times in buried nodules from red clay compared to siliceous ooze. However, the mode of incorporation of REE into buried nodules from both sedimentary environments is by a single authigenic phase consisting of Fe-Ti-P. Shale-normalized REE patterns and Ce anomalies suggest that nodules from siliceous ooze formed under more oxidizing conditions than those from red clay. Nodules buried at depths between $1.5 \mathrm{~m}$ to $2.5 \mathrm{~m}$ are diagenetic (Mn/Fe ratio 10-15), formed in highly oxic environments (large positive Ce anomalies) and record aeolian dust (high Eu anomalies). Chemical composition, surface texture and morphology of buried nodules are similar to those of surface nodules from the same basin. Furthermore, buried nodule compositions do not exhibit any distinct patterns within the core depth, suggesting that buried nodules neither grow nor dissolve after their burial in the sediment column.
\end{abstract}

Keywords: Central Indian Ocean Basin, buried nodules, size, composition, origin, siliceous ooze, red clay, 
*Corresponding author: pattan@nio.org, Telephone: 91 -832-2450360, Fax: 91-832-2450602.

\section{Introduction}

The occurrence of buried manganese nodules is less well known than that of surface nodules. Various processes have been suggested to explain the phenomenon of keeping manganese nodules at the sediment-water interface. Possible mechanisms to maintain nodules at the sediment-water interface could be the influence of ocean bottom currents and the reworking of sediment by benthic organisms (Glasby, 1977; Glasby et al., 1982). Alternatively, due to the small density difference between the nodules $\left(1.96 \mathrm{~g} / \mathrm{cm}^{3}\right)$ and associated sediment $\left(1.33 \mathrm{~g} / \mathrm{cm}^{3}\right)$, only a small upward force is enough to maintain them at the sediment - water interface (Glasby, 1977; von Stackelberg, 1984). The nodules that are left behind during uplift are kept buried within the sediment. However, the processes of maintaining nodules at the sediment-water interface still remain unclear. Once nodules are buried within the sediment column, they are considered to be in a closed system. In such a case, it is important to know what happens to them after burial. There are three possibilities once a nodule is buried: it will continue to grow, cease to grow or dissolve. Cronan (1973) observed growth of manganese nodules in sediment cores from Deep Sea Drilling Projects. Heye et al (1979) also showed that there are strong indications that the nodules probably continued to grow after burial. Subsequently, Cronan (1976) found that nodules at $130 \mathrm{~m}$ in the sediment column showed evidence of dissolution. By contrast, Heye (1975) suggested that there is no indication of partial dissolution of buried nodules. Somayajulu et al. (1971) suggested that manganese nodules cease to grow after their burial based on $I_{0}$ activity in the equatorial Pacific Ocean. Most of these studies are restricted to the Pacific or Atlantic Oceans and there are few reports on the occurrence of buried nodules in the CIOB (Banerjee et al., 1991; Pattan and Banakar, 1993; Pattan and Parthiban, 2006). In the present work, we have studied the size, surface texture, morphology and chemical composition of 50 buried nodules recovered from 12 sediment cores (10 from siliceous ooze and 2 from red clay) in order to understand their behavior within the sediment column after burial.

\section{Materials and Methods}

During the last two decades under the Indian Polymetallic Nodules exploration program in the CIOB, more than 60 sediment cores up to $6 \mathrm{~m}$ long were collected during different 
expeditions (Fig.1). These sediment cores were recovered between $4^{\circ} \mathrm{N}$ to $18^{\circ} \mathrm{S}$ and $72^{\circ} \mathrm{E}$ to $88^{\circ}$ E. The water depth in the area varies from 4740 to $5800 \mathrm{~m}$. Only 12 sediment cores contained buried nodules. A total of 50 buried nodules were recovered from these cores. Buried nodules were hand picked from the sediment core, cleaned with water to remove the adhered sediment and were characterized by their size, morphology, surface texture and chemical composition. Oxide layers of the dried buried nodules were separated, powdered and digested using a mixture of $\mathrm{HF}+\mathrm{HClO}_{4}+\mathrm{HNO}_{3}$. Major and minor elements were analysed with Inductively Coupled Plasma-Optical Emission Spectrometer (ICP-OES) at National Institute of Oceanography, Goa For trace and rare earth elements, solutions were prepared following the procedure of Balaram and Rao (2003) and analysed by Inductively Coupled Plasma-Mass Spectrometer (ICP-MS) at National Geophysical Research Institute, Hydrabad. Accuracy of the data was checked by using international standard reference materials (A-1 and P-1) and precisions based on duplicate samples were found to be better than $\pm 5 \%$.

\section{Results and Discussion}

\subsection{Distribution of buried nodules}

The distribution of buried nodules with depth in the cores is shown in Fig.2. Out of 60 cores recovered, only 10 are from siliceous ooze in the northern part of study area and 2 are from red clay area located at the southernmost part of study area have buried nodules. The occurrences of buried nodules start from $8^{\circ} \mathrm{S}$ and are more abundant between $15^{\circ}$ to $18^{\circ} \mathrm{S}$ (Fig.1). However, buried nodules were sampled from 6-inch diameter gravity cores and their recovery was therefore matter of chance. A total of 50 buried nodules was collected within the top $6 \mathrm{~m}$ of the sediment cores, of which 43 are from siliceous ooze and 7 from the red clay area. Buried nodules were observed a few hundred meters below the sea floor in DSDP/ODP cores (Glasby, 1978; Usui and Ito, 1994). Later it was suspected that the occurrence of buried nodules was due to slumping of the upper sedimentary layer during drilling operations (McManus et al., 1970; Cronan, 1973). Subsequently, Ito et al. (1998) suggested that the occurrence of buried nodules in DSDP/ODP sites was not due to slumping. In the CIOB, all buried nodules were recovered by gravity cores and therefore there was no possibility of slumping of nodules from the surface. The distribution of buried nodules within the sediment core is random and most of the buried nodules appear to occur in the top $1 \mathrm{~m}$ of the core. A maximum of 15 buried nodules were recovered in one sediment core (AAS-22/GC-07) and the maximum depth of occurrence is at $5.5 \mathrm{~m}$ below the seafloor in a sediment core (AAS-04/GC-5A) from siliceous ooze (Fig.2). The sediment cores from red clay area were sampled by spade core with a maximum core length of $45 \mathrm{~cm}$. The 
maximum depth of occurrence of buried nodules in these cores is $30 \mathrm{~cm}$ below the seafloor. Martin-Barajas et al. (1991) collected sediment cores up to $18 \mathrm{~m}$ long in CIOB and observed that the maximum depth of occurrence of buried nodules was $\sim 4.3 \mathrm{~m}$ below the seafloor. In the Pacific Ocean, Stoffers et al. (1982) and Glasby et al. (1982) and Thijssen et al. (1985) encountered 27 nodules buried between depths of 0.73 and $2.50 \mathrm{~m}$ in four long box cores. Von Stackelberg (2000) recovered 177 buried nodules from SO-79 and SO-106 cruises in the Pacific Ocean that were buried in sediment deeper than $20 \mathrm{~cm}$, with the deepest nodule at a depth of 16.2 m. It appears that buried nodules are more abundant in the Pacific than in the Indian Ocean. This probably reflects the lower average sedimentation rate in the Pacific Ocean compared to the Indian ocean (Glasby, 1991). Occurrence of buried nodules in the Indian Ocean is restricted to greater water depth or valleys than the seamount slopes. This is similar to the observation made in the Pacific Ocean (von Stackelberg, 2000).

\subsection{Buried nodules size, morphology and surface texture}

The buried nodules vary in size from $2 \mathrm{~cm}$ to $11 \mathrm{~cm}$. One of the nodules buried at $93 \mathrm{~cm}$ depth (SK-176) is $11 \mathrm{~cm}$ in diameter and looks like a crust. Thirty eight nodules out of 50 are only $\sim 2 \mathrm{~cm}$ in diameter. This suggests that nearly $80 \%$ of the buried nodules are of small size. The majority of surface nodules are between 2 to $6 \mathrm{~cm}$ in diameter (Banakar et al., 1989; Valsangkar and Khadge, 1989). In the Peru Basin, Pacific Ocean, nearly 50\% of buried nodules are $>6 \mathrm{~cm}$ and $21 \%$ are $>10 \mathrm{~cm}$ in diameter and these buried nodules are larger than surface nodules $(2.4 \mathrm{~cm})$ (von Stackelberg, 2000). Similarly in the Atlantic Ocean, buried nodules range between 2 and $8 \mathrm{~cm}$ with the majority of them $\sim 8 \mathrm{~cm}$ in diameter (Glasby, 1978). Buried nodule sizes decrease with core depth. The buried nodules in the CIOB are therefore smaller than those from the Pacific and Atlantic Oceans. By contrast, Heath (1979) observed that the burial depth of nodules is independent of size. Glasby (1977) suggested that bottom currents and bioturbation are responsible for keeping the nodules at the sediment - water interface. The presence of larger buried nodules in both the Pacific and Atlantic Oceans could be due to less bioturbation and bottom currents. Smaller sized nodules are more mobile than larger nodules. The presence of small-buried nodules at greater depths in the sediment column could be similar to the phenomena of the "Brazil Nut Effect" where tectonic/sieving like processes operate. Due to their large size, nodules are always kept at the top and smaller at the bottom. A similar observation was made by Prasad et al. (2003) where they found that Australasian tektite in the upper layer of sediment and microtektite in the subsurface were the same age. The Brazil Nut Effect term was based on the observations made on the Brazil nuts and has been known since 1930. The factors responsible for 
the Brazil nut effect are size and density of particles and presence of any gas between particles. When materials are shaken, voids are continuously created beneath the grains. The smaller grains/nodules are more likely to fall in and fill the available space.

The buried nodules from siliceous ooze exhibit both smooth and rough surface textures whereas those from red clay have only smooth surfaces. The morphology of the buried nodules vary and include ellipsoidal, elongated, spheroidal, sub-rounded, irregular and polynucleated shapes. The surface texture and morphology of the buried nodules are similar to surface nodules from the CIOB (Jauhari, 1990).

\subsection{Chemical composition of buried nodules}

The chemical composition of buried nodules from siliceous ooze (SK-16, AAS-40 /GC03) and red clay (AAS-62/-55 and AAS-62/-56), along with surface nodule data, are presented in Tables 1, 2 \& 3 respectively. The compositional variation of nodules is mainly governed by the depositional environment and supply of elements either from the overlying seawater or by diagenetic supply through pore water from the underlying sediment. The Mn and Fe contents of nodules from siliceous ooze vary from $18.7 \%$ to $29.1 \%$ and $1.73 \%$ to $14.1 \%$, respectively. Those from the red clay range from 17.4 to $20.9 \%$ and 8.1 to $11.1 \%$, respectively. $\mathrm{Cu}, \mathrm{Ni}, \mathrm{Zn}$, Mo, Ga, V and Rb contents in buried nodules from the siliceous ooze are higher than those in red clay The enriched elements in the siliceous ooze nodules are associated with diagenetic remobilization processes via pore waters, whereas the enriched elements in buried nodules from red clay are derived from the overlying seawater column. Aplin and Cronan (1985) suggested that decomposition and oxidation of organic matter and dissolution of biogenically associated elements such as $\mathrm{Mn}, \mathrm{Cu}$ and $\mathrm{Ni}$ are released and incorporated into nodules. This leads to enrichment of $\mathrm{Mn}, \mathrm{Cu}, \mathrm{Ni}$ and $\mathrm{Zn}$ in the buried nodules from siliceous ooze. The Mn/Fe ratios of buried nodules from siliceous ooze suggest a hydrogentic, early diagenetic and diagenetic origin (Halbach et al., 1981). In the CIOB, the red clay area extends beyond $15^{\circ} \mathrm{S}$ and is associated with low sedimentation rates, preserved biogenic components and low primary productivity (Parson et al., 1977). This area is associated with a large number of authigenic components such as manganese micronodules, smectite, and biogenic apatite. Buried nodules from the red clay are enriched in Fe, Co, Ti, U, Th, Y, Cr and Nb possibly supplied by the overlying water (Halbach et al., 1981). The Mn/Fe ratios of these nodules are $<2.5$, indicating that they are of hydrogenetic origin.

REE are used to understand the depositional environment of ferromanganese oxide deposits. Among the REE, cerium has a dual oxidation state and is more useful in understanding 
the redox conditions of the depositional environment (Elderfield et al., 1981; Glasby et al., 1987). We considered La as a representative element of the REE group because all of the 14 naturally occurring elements were not analysed in all of the studied samples. The mean La content in the buried nodules from red clay is $166 \mathrm{ppm}$ and enriched more than 1.5 times compared to nodules in siliceous ooze (89 ppm) (Tables. 1, 2 \& 3). The total REE content of buried nodules occurring between $1.5 \mathrm{~m}$ to $2.5 \mathrm{~m}$ depth within the sediment column is very low (Table.2) and is associated with high $\mathrm{Mn} / \mathrm{Fe}$ ratios (9 to 14 ), which is indicative of a strong diagenetic signature. The low REE abundance associated with high $\mathrm{Mn} / \mathrm{Fe}$ ratios suggests that the REE are not supplied by diagenetic processes to nodules. To understand the REE carrier phase in buried nodules, we plotted La (representing REE group) against combined $\mathrm{Fe}+\mathrm{Ti}+\mathrm{P}$ contents, which shows a strong positive correlation $(r=0.88)$, suggesting a single REE carrier phase (Fig. 3). This is similar to the earlier observation of a single carrier phase (Glasby et al., 1987; Pattan and Banakar, 1993; Jauhari and Pattan, 2000) rather than two independent carrier phases (Elderfield et al., 1981; Nath et al., 1992). The shale- normalized REE pattern of buried nodules shows a convex pattern (middle REE enrichment) with a strong Ce enrichment (Fig. 4). The Cerium anomaly varies from 0.16 to 0.84 with an average of 0.4 in siliceous ooze nodules and 0.26 to 0.38 with an average of 0.3 in red clay. This suggests that buried nodules from siliceous ooze formed under more oxidizing conditions than red clay nodules. These highly oxic conditions could probably be due to the supply of enhanced Antarctic Bottom Water through the saddles of Ninety East Ridge at $5^{\circ} \mathrm{S}$ in the siliceous area of CIOB. The buried nodules in the top $50 \mathrm{~cm}$ of the sediment column exhibit comparatively smaller Ce anomalies, whereas those buried between 1.5 to $2.5 \mathrm{~m}$ depths have higher Ce anomalies suggesting their formation under more oxic condition (Fig. 5 \& 6). The Europium (Eu) anomalies in the marine environment could be due to the influence of hydrothermal processes, aeolian dust and excess sodium feldspars (Elderfield, 1988; Murray et al., 1991). The Eu anomaly is almost absent in the nodules from red clay. A very small Eu anomaly is observed in the nodules buried in the upper $50 \mathrm{~cm}$ of siliceous ooze, but a strong Eu anomaly (0.17 to 0.23 ) is observed in nodules buried between 1.5 to $2.5 \mathrm{~m}$ in the sediment column (Fig $5 \& 6$ ).. The absence of a negative Ce anomaly and relatively high concentration of trace elements shows that there was no hydrothermal input into nodule formation. The other contender for Eu anomalies is the presence of sodium feldspar. The location of the manganese nodule field is far from mid-oceanic ridges and thus rules them out as a cause for the Eu anomaly. The presence of a strong Eu-anomaly could therefore be due to trapping of aeolian dust in the nodules. Although it is not valid to compare the chemical data of buried nodules and associated sediments because of different accumulation rates, it is worth mentioning that a relatively strong 
Eu anomaly was observed in a nearby sediment core between $76 \mathrm{~cm}$ and $290 \mathrm{~cm}$ depth in CIOB (Pattan et al., 2005).

The concentrations of transition elements in buried and surface nodules from both siliceous and red clay areas are almost in the same range (Jauhari, 1990; Table 4 \& 5). The concentrations of a few representative elements, along with Mn/Fe ratios, Ce and Eu-anomalies for a few buried nodules within the sediment column are shown in Fig. 5. The distribution of elements in the buried nodules from red clay is almost uniform, suggesting that no change occurred after burial within the sediment column. In the CIOB, a suboxic zone is located between $\sim 10$ and $15 \mathrm{~cm}$ depth in the sediment column based on the minimum solid Mn content in a large number of cores from the manganese nodule - bearing area of siliceous ooze (Pattan and Mudholkar 1990; Banakar et al., 1991; Mudholkar et al., 1991; Pattan, 1993). This suboxic zone is responsible for the lower micronodule abundance, dissolution of micronodules resulting in smaller size and their low Mn, Cu, Ni and Zn content (Pattan, 1993). However, the sediments above the suboxic zone show high $\mathrm{Mn}, \mathrm{Cu}$ and $\mathrm{Ni}$ contents, suggesting diagenetic remobilization of these elements due to dissolution of micronodules. The micronodules present above the suboxic zone are enriched in $\mathrm{Mn}, \mathrm{Cu}$ and $\mathrm{Ni}$ due to diagenetic remobilization. In the present study, buried nodules were not recovered from the suboxic zone. Buried nodules between $3.25 \mathrm{~m}$ to $4.25 \mathrm{~m}$ depth in sediment core (AAS-40/GC-03), have low $\mathrm{Mn}$. $\mathrm{Cu}$ and $\mathrm{Ni}$ contents but the sediment between $1 \mathrm{~m}$ to $5 \mathrm{~m}$ depth have almost uniform Mn content ( $0.5 \%$ to $0.6 \%$ ) and other transition metals (Parthiban, 2005; Pattan et al., 2005). If these buried nodules are being dissolved, then one would expect the upward diagenetic remobilization of transition metals within the sediment column. The absence of diagenetic remobilization of transition metals in the deeper part of the sediment column suggests that no such dissolution is taking place. Once the nodules are buried within the sediment column, it therefore appears that they neither grow nor dissolve.

\section{Conclusions}

Based on the present investigation the following conclusions are made:

1. Buried nodule sizes decrease with increasing core depth. This is similar to the phenomenon of the "Brazil Nut Effect " where larger objects/nodules are always kept on top and smaller once in the subsurface.

2. Buried nodules morphology, surface texture and chemical composition are similar to the surface nodules. 
3. Buried nodule compositions do not exhibit any variation with core depth and the absence of diagenetic remobilization of transition metals in the associated sediment column suggest that buried nodules neither grow nor dissolve.

\section{Acknowledgements}

Authors thank Director, NIO, Goa for the permission to publish this paper. Thanks are due to Dr. Anjali Chodankar and Dr. V. Balaram, for ICP-OES and ICP-MS analysis respectively. We are grateful to Dr. G.P.Glasby for his constructive comments and suggestions and Dr. Kelvin Burke, Editor in Chief for the editorial corrections. Dr. M. Shyam Prasad is thanked for providing buried nodules from two sediment cores. This is NIO contribution No. 4247. 


\section{REFERENCES}

Aplin, A.C., Cronan, D. S., 1985. Ferromanganese oxide deposits from the Central Pacific Ocean. II. Nodules and associated sediments. Geochim Cosmochim Acta 49, 437- 451. .

Balaram, V., Rao, T.G., 2003. Rapid determination of REE`s and other trace elements in geological samples by microwave acid digestion and ICP-MS. Atomic Spectroscopy 24(6), 206-212.

Banakar, V.K., Gupta, S.M., Padmavati, V.K., 1991. Abyssal sediment erosion in the Central Indian Basin: evidence from radio-chemical and radiolarian studies. Marine Geology 96, 161-173.

Banakar, V.K., Pattan, J.N., Jauhari, P., 1989. Size, surface texture, chemical composition and mineralogy interrelations in ferromanganese nodules from Central Indian Ocean. Indian Journal of Marine Sciences 18, 201-203.

Banerjee, R., Iyer, S.D., Dutta, P., 1991. Buried nodules and associated sediments from the Central Indian Basin. Geo-Maine Letters 11, 103-107.

Cronan, D.S., 1973. Manganese nodules in sediment cored during Lag 16, Deep Sea Drilling Project. Int.Rep. DSDP. 5, 605-608.

Cronan, D.S., 1976. Deep sea nodules-distribution and geochemistry In : Glasby, G.P (Ed): Marine manganese deposits, Elsevier Oceanographic Series, 15, Amsterdam, 217-263.

Elderfield, H., Hawkesworth, C.J., Greaves, M.J., Calvert, S.E., 1981. Rare earth element geochemistry of oceanic ferromanganese nodules and associated sediments. Geochim Cosmochim Acta. 45, 1231-1234.

Elderfield, H., 1988. The oceanic chemistry of the rare earth elements. Phils. Trans. Royal Society London. Ser. A.325, 105-126.

Glasby, G. P., 1977. Why manganese nodules remain at the sediment-water interface. New Zealand Journal of Science 20, 187-190.

Glasby, G. P., 1978. Deep - sea manganese nodules in the stratigraphic record: Evidence from DSDP cores. Marine Geology 28, 51-64.

Glasby. G. P., 1991. Mineralogy, geochemistry and origin of Pacific Ocean manganese nodules. New Zealand Journal of Geology and Geophysics 34, 167-176.

Glasby, G.P., Stoffers, P., Sioulas, A., Thijssen, T., Friedrich, G., 1982. Manganese nodule formation in the Pacific Ocean: a general theory. Geo-Maine Letters 2, 47-53.

Glasby, G.P., Gwozdz, R., Kunzendorf, H., Freidrich, G., Thijssen, T., 1987. The distribution of rare earth and minor elements in manganese nodules and sediments from the equatorial and SW Pacific. Lithos 20, 97-113. 
Halbach, P., Scherhag, C., Hebisch, U., Marchig, V., 1981. Geochemical and mineralogical control of different genetic types of deep-sea nodules from the Pacific Ocean. Mineral Deposita 16, 59-84.

Heath, G. R., 1979. Burial rates, growth rates and size distribution of deep sea manganese nodules. Science 205, 903-904.

Heye, D., 1975. Wachstumverhaltnisse von Manganknollen. Deo Jahrab Reihe E 5, 3-122.

Heye, D., Marchig, V., Meyer, H., 1979. The growth of buried manganese nodules. Deep Sea Research. 26A, 789-798.

Ito, J., Usui, A. Kajiwara,Y., Nakara, J., 1998. Strontium isotopic composition and paleoceanographic implication of fossil manganese nodules in DSDP.ODP cores, Leg 1126. Geochim. Cosmochim. Acta. 62(9), 1545-1554.

Jauhari, P., 1990. Relationship between morphology and composition of manganese nodules from the Central Indian Ocean. Marine Geology 92, 115-125.

Jauhari, P., Pattan, J.N., 2000. Ferromanganese nodules from the Central Indian Ocean Basin. In: Handbook of Marine Mineral Deposits. D.S.Cronan (ed), CRC Press, pp:171-195.

Martin-Barajas, A. Lallier-Verges,E., Leclaire, L., 1991. Characteristics of manganese nodules from the Central Indian Basin: Relationship with the sedimentary environment. Marine Geology 101, 249-265.

McManus, D.A., Weeser, O., Von Der Borch, C.C., Vallier, T., Burns, R. E., 1970. Regional aspects of Deep Sea Drilling in the Northeast Pacific. Int. Rep. DSDP. 5, 621-636.

Mudholkar, A.V., Pattan, J.N., Parthiban, G., 1991. Geochemistry of deep sea sediment cores from the Central Indian Ocean Basin. Indian Journal of Marine Sciences 22, 241-246.

Murray, R.W., Brink, M.R.B., Gerlach, D.C., Russ, G.P., Jones, D.L., 1991. Rare earth, major and trace elements in chert from the Franciscan Complex and Monterery group, California: Assessing REE sources to fine grained marine sediments. Geochim Cosmochim Acta 55, 1875-1895.

Nath, B.N., Balaram, V., Sudhakar, M., Pluger, W.L., 1992. Rare earth element geochemistry of ferromanganese deposits from the Indian Ocean. Marine Chemistry 38, 185-208.

Parsons, T.R.M., Takahashi, M., Hargrove, B., 1977. Biological oceanographic processes. $2^{\text {nd }}$ Edition, Pergmon, New York. Pp.332.

Pattan, J.N., Mudholkar, A.V., 1990. The oxidation state of manganese in ferromanganese nodules and deep-sea sediments from the Central Indian Ocean. Chemical Geology 85, 171-181. 
Pattan, J.N., Banakar, V.K., 1993. Rare earth element distribution and behaviour in buried manganese nodules from the Central Indian Basin. Marine Geology 112, 303-312.

Pattan, J. N., 1993. Manganese micronodules: A possible indicator of sedimentary environments. Marine Geology 113, 331-344.

Pattan, J.N., Pearce, N. J. G., Mislankar, P.G., 2005. Constraints in using cerium anomaly of bulk sediments as an indicator of paleo bottom water redox environment: A case study from the Central Indian Ocean Basin. Chemical Geology 221, 260-278.

Pattan, J.N., Partibhan, G., 2006. Composition and origin of buried ferromanganese nodules from Central Indian Basin. Journal Geological Society of India 68, 605-609.

Parthiban, G., 2005. Quaternary sedimentation in the Central Indian Ocean Basin: Response to Himalayan weathering and climatic variation. Unpublished Ph.D Thesis.Goa University, Goa. Pp.121.

Prasad, M. S., Gupta, S.M., Kodagali, V.N., 2003. Two layers of Australasian impact ejecta in the Indian Ocean ?. Meteorites \& Planetary Sciences 38 (9), 1373-1381.

Somayajulu, B.L.K., Heath, G.R., Moore, T.C., Cronan, D.S., 1971. Rates of accumulation of manganese nodules and associated sediment from the equatorial Pacific. Geochim. Cosmochim Acta 35, 621-624.

Stoffers, P., Sioulas, A., Glasby, G. P., Thijssen, T., 1982. Geochemical and sedimentalogical studies of a box core from the western sector of the Peru Basin. Marine Geology 49, 273297.

Thijssen,T., Glasby, G.P, Friedrich, G., Stoffers, P., Sioulas, A., 1985. Manganese nodules in the Central Peru Basin. Chemie der Erde. 44, 1- 12.

Usui, A., Ito, T., 1994. Fossil manganese deposits buried within DSDP /ODP cores, Legs 1-126. Marine Geology 119, 111-136.

Valsangkar, A.B., Khadge, N.H., 1989. Size analysis and geochemistry of ferromanganese nodules from the Central Indian Ocean Basin. Marine Mining 8, 325-347.

Von Stackelberg, U., 1984. Significance of benthic organisms for the growth and movement of manganese nodules, Equatorial North Pacific. Geo-Marine Letters 4, 37-42.

Von Stackelberg, U., 2000. Manganese nodules of the Peru Basin. In: Hand book of Marine Mineral Deposits (ed) Cronan, D.S. CRC Press, 197-238. 
Table.1 Chemical composition of buried manganese nodules in a sediment core (SK-176) from siliceous ooze (Pattan and Banakar, 1993) in the Central Indian Ocean Basin.

\begin{tabular}{|c|c|c|c|c|c|c|c|c|}
\hline Elements & $2.0 \mathrm{~cm}$ & $8.7 \mathrm{~cm}$ & $15.2 \mathrm{~cm}$ & $19.0 \mathrm{~cm}$ & $22.5 \mathrm{~cm}$ & $23.5 \mathrm{~cm}$ & $27.5 \mathrm{~cm}$ & $92.5 \mathrm{~cm}$ \\
\hline Al (\%) & 1.95 & 3.86 & 2.52 & 3.70 & 3.95 & 2.34 & 2.88 & 2.40 \\
\hline $\mathbf{F e}$ & 11.2 & 8.65 & 12.1 & 8.58 & 8.16 & 10.6 & 10.3 & 14.1 \\
\hline Mn & 29.2 & 22.7 & 24.6 & 24.9 & 25.0 & 26.8 & 25.9 & 27.4 \\
\hline $\mathbf{T i}$ & 0.40 & 0.32 & 0.38 & 0.30 & 0.28 & 0.34 & 0.32 & 0.43 \\
\hline Ca & 1.70 & 1.42 & 1.54 & 1.49 & 1.45 & 1.60 & 1.42 & 1.34 \\
\hline Mg & 1.82 & 1.62 & 1.83 & 2.02 & 2.29 & 2.46 & 1.92 & 1.36 \\
\hline $\mathrm{Na}$ & 1.69 & 2.23 & 1.54 & 1.96 & 1.87 & 1.49 & 1.51 & 1.55 \\
\hline $\mathbf{K}$ & 0.53 & 1.68 & 0.64 & 1.22 & 1.24 & 0.61 & 2.51 & 0.60 \\
\hline$\overline{\mathbf{P}}$ & 0.22 & 0.19 & 0.23 & 0.17 & 0.17 & 0.21 & 0.18 & 0.17 \\
\hline Cu (ppm) & 7862 & 6422 & 7994 & 7910 & 9725 & 9153 & 9056 & 4977 \\
\hline $\mathbf{N i}$ & 11654 & 9271 & 9020 & 11214 & 11906 & 11542 & 11308 & 6520 \\
\hline Zn & 1457 & 982 & 999 & 1108 & 1208 & 1210 & 1140 & 716 \\
\hline Co & 1797 & 1308 & 1740 & 1387 & 1263 & 1728 & 1573 & 1746 \\
\hline $\mathbf{P b}$ & 1027 & 715 & 919 & 683 & 592 & 916 & 807 & 1095 \\
\hline Mo & 571 & 466 & 562 & 523 & 496 & 630 & 576 & 348 \\
\hline $\mathbf{L i}$ & 68 & 59 & 61 & 94 & 115 & 88 & 91 & 8 \\
\hline Ba & 1325 & 1065 & 1597 & 1347 & 811 & 1591 & 1504 & 1416 \\
\hline $\mathbf{Y}$ & 120 & 96 & 126 & 92 & 78 & 121 & 104 & 101 \\
\hline $\mathbf{L a}$ & 159 & 115 & 171 & 112 & 92 & 159 & 130 & 80 \\
\hline Ce & 760 & 499 & 812 & 434 & 323 & 659 & 526 & 492 \\
\hline Nd & 178 & 137 & 182 & 135 & 112 & 180 & 146 & 86 \\
\hline Sm & 37.4 & 29.5 & 37.7 & 29.8 & 24.9 & 37.8 & 31.6 & 19.1 \\
\hline Eu & 8.8 & 7.0 & 8.9 & 7.1 & 6.1 & 9.1 & 7.7 & 4.5 \\
\hline Gd & 39.0 & 30.2 & 40.4 & 29.5 & 25.0 & 39.4 & 33.0 & 20.6 \\
\hline Dy & 32.0 & 24.5 & 33.0 & 24.3 & 21.0 & 32.7 & 27.5 & 17.0 \\
\hline Ho & 5.6 & 4.5 & 6.1 & 4.6 & 4.1 & 6.1 & 5.2 & 3.1 \\
\hline Er & 16.0 & 12.3 & 17.0 & 12.3 & 10.7 & 15.7 & 13.9 & 8.5 \\
\hline $\mathbf{Y b}$ & 14.0 & 10.8 & 15.3 & 10.8 & 7.9 & 9.5 & 12.8 & 8.0 \\
\hline Lu & 2.3 & 1.8 & 2.5 & 1.8 & 1.3 & 1.3 & 2.1 & 1.4 \\
\hline
\end{tabular}


Table.2. Chemical composition of the buried manganese nodules in a sediment core (AAS40/GC-03) from siliceous ooze

in the Central Indian Ocean Basin ( Pattan and Parthiban, 2006).

\begin{tabular}{|c|c|c|c|c|c|}
\hline Element & $\begin{array}{l}\text { 167-169 } \\
\mathrm{cm}\end{array}$ & $\begin{array}{l}172-174 \\
\text { cm }\end{array}$ & $\begin{array}{l}226-228 \\
\mathrm{~cm}\end{array}$ & $\begin{array}{l}\text { 328-330 } \\
\text { m }\end{array}$ & $\begin{array}{l}\text { 418-420 } \\
\mathrm{m}\end{array}$ \\
\hline Mn (\%) & 26.1 & 27.5 & 27.3 & 13.3 & 18.8 \\
\hline $\mathbf{F e}$ & 1.73 & 2.95 & 2.12 & 8.49 & 6.25 \\
\hline Ti & 0.10 & 0.14 & 0.12 & 0.35 & 0.22 \\
\hline $\mathbf{P}$ & 0.051 & 0.056 & 0.050 & 0.078 & 0.075 \\
\hline Sc (ppm) & -- & 419 & 481 & 169 & 101 \\
\hline V & 1297 & 961 & 692 & 592 & 687 \\
\hline $\mathrm{Cr}$ & 24.5 & 33.5 & 31.3 & 27.9 & 27.7 \\
\hline Co & 270 & 700 & 580 & 1480 & 1080 \\
\hline $\mathrm{Ni}$ & 5110 & 7210 & 6500 & 3490 & 9470 \\
\hline $\mathbf{C u}$ & 13560 & 14380 & 14410 & 4050 & 4300 \\
\hline Zn & 450 & 630 & 660 & 370 & 770 \\
\hline Ga & 19.7 & 27.9 & 29.5 & 20.4 & 32.3 \\
\hline $\mathbf{R b}$ & 26.1 & 182 & 159 & 53.5 & 28.8 \\
\hline $\mathrm{Sr}$ & 598 & 649 & 556 & 602 & 514 \\
\hline $\mathbf{Y}$ & 23.7 & 12.6 & 15.1 & 34.6 & 31.3 \\
\hline $\mathrm{Zr}$ & 62 & 573 & 487 & 359 & 171 \\
\hline Nb & 24.6 & 15.7 & 11.6 & 17.4 & 12.0 \\
\hline Mo & 782 & 753 & 733 & 418 & 634 \\
\hline Cs & 1.07 & 0.65 & 0.81 & 1.01 & 1.01 \\
\hline La & 38.6 & 4.52 & 6.53 & 56.6 & 41.9 \\
\hline $\mathrm{Ce}$ & 329 & 110 & 154 & 385 & 281 \\
\hline Pr & 7.83 & 2.05 & 2.52 & 12.5 & 8.81 \\
\hline Nd & 38.64 & 24.13 & 16.93 & 48.52 & 35.15 \\
\hline Sm & 9.49 & 4.55 & 4.46 & 12.2 & 8.92 \\
\hline Eu & 3.05 & 1.75 & 1.61 & 3.06 & 2.30 \\
\hline Gd & 8.71 & 4.57 & 4.22 & 11.9 & 9.11 \\
\hline Tb & 1.41 & 0.98 & 0.90 & 2.20 & 1.72 \\
\hline Dy & 7.05 & 4.94 & 4.95 & 11.0 & 9.29 \\
\hline Ho & 1.59 & 1.07 & 1.14 & 2.47 & 2.20 \\
\hline Er & 3.04 & 1.99 & 2.16 & 4.60 & 4.23 \\
\hline Tm & 0.58 & 0.44 & 0.46 & 0.88 & 0.84 \\
\hline $\mathbf{Y b}$ & 3.77 & 2.96 & 3.08 & 5.66 & 5.51 \\
\hline $\mathbf{L u}$ & 0.54 & 0.45 & 0.49 & 0.85 & 0.85 \\
\hline Hf & 1.09 & 12.17 & 11.62 & 8.11 & 4.19 \\
\hline Ta & 0.33 & 0.50 & 0.87 & 0.82 & 0.55 \\
\hline $\mathbf{P b}$ & 1116 & 800 & -- & 914 & 1032 \\
\hline Th & 9.95 & 4.24 & 6.11 & 48.4 & 33.8 \\
\hline $\mathbf{U}$ & 1.89 & 3.04 & 2.67 & 2.67 & 2.24 \\
\hline
\end{tabular}


Table. 3. Chemical composition of buried manganese nodules in two sediment cores

(AAS-62/55, AAS-62/56) from the red clay in the Central Indian Ocean Basin.

\begin{tabular}{|c|c|c|c|c|c|c|c|}
\hline & AAS-62/55 & AAS-62/55 & AAS-62/55 & AAS-62/55 & AAS-62/56 & AA-/62/56 & AAS-62/56 \\
\hline Elements & $-02 \mathrm{~cm}$ & $-08 \mathrm{~cm}$ & $-12 \mathrm{~cm}$ & $-25 \mathrm{~cm}$ & $-02 \mathrm{~cm}$ & $-05 \mathrm{~cm}$ & $-30 \mathrm{~cm}$ \\
\hline Mn (\%) & 18.4 & 20.5 & 20.9 & 19.6 & 19.4 & 17.5 & 17.4 \\
\hline $\mathbf{F e}$ & 9.80 & 8.78 & 8.15 & 8.14 & 10.4 & 10.4 & 11.2 \\
\hline $\mathbf{T i}$ & 0.43 & 0.35 & 0.33 & 0.32 & 0.43 & 0.42 & 0.47 \\
\hline $\mathbf{P}$ & 0.032 & 0.019 & 0.019 & 0.026 & 0.026 & 0.024 & 0.011 \\
\hline $\mathrm{Cu}$ (ppm) & 3449 & 4727 & 4745 & 4678 & 3750 & 3499 & 3556 \\
\hline $\mathbf{N i}$ & 7115 & 9295 & 9451 & 8523 & 8045 & 6765 & 5921 \\
\hline Co & 2105 & 1734 & 1642 & 1665 & 2008 & 1951 & 2000 \\
\hline Zn & 686 & 891 & 895 & 908 & 767 & 675 & 603 \\
\hline $\mathbf{P b}$ & 818 & 704 & 696 & 664 & 826 & 746 & 951 \\
\hline $\mathbf{L i}$ & 83 & 99 & 105 & 101 & 56 & 55 & 42 \\
\hline Sc & 9.0 & 8.0 & 8.0 & 8.0 & 8.0 & 10.0 & 9.0 \\
\hline $\mathbf{V}$ & 586 & 514 & 509 & 477 & 473 & 495 & 475 \\
\hline $\mathrm{Cr}$ & 531 & 240 & 251 & 280 & 378 & 284 & 264 \\
\hline Co & 3370 & 3394 & 3444 & 3436 & 3427 & 3430 & 3420 \\
\hline Zn & 1339 & 1493 & 1520 & 1489 & 1190 & 1168 & 891 \\
\hline Ga & 14.0 & 12.0 & 12.0 & 11.0 & 10.0 & 11.0 & 13.0 \\
\hline $\mathbf{R b}$ & 15.0 & 14.0 & 15.0 & 19.0 & 11.0 & 14.0 & 13.0 \\
\hline $\mathbf{Y}$ & 111 & 101 & 99 & 94 & 109 & 117 & 94 \\
\hline $\mathrm{Zr}$ & 521 & 429 & 399 & 395 & 479 & 567 & 570 \\
\hline $\mathbf{N b}$ & 49 & 38 & 37 & 38 & 45 & 52 & 54 \\
\hline Mo & 611 & 597 & 605 & 554 & 436 & 479 & 382 \\
\hline Cs & 0.6 & 0.5 & 0.6 & 0.7 & 0.5 & 0.5 & 0.5 \\
\hline Ba & 1733 & 1783 & 1821 & 1831 & 1785 & 1769 & 1771 \\
\hline Hf & 10.0 & 8.0 & 7.0 & 8.0 & 9.0 & 11.0 & 11.0 \\
\hline La & 184 & 158 & 152 & 141 & 171 & 184 & 178 \\
\hline Ce & 703 & 709 & 720 & 719 & 716 & 717 & 715 \\
\hline Pr & 38.0 & 34.0 & 33.0 & 30.0 & 37.0 & 39.0 & 38.0 \\
\hline Nd & 155 & 123 & 121 & 116 & 148 & 142 & 159 \\
\hline $\mathrm{Sm}$ & 37.0 & 33.0 & 32.0 & 30.1 & 36.1 & 37.2 & 36.2 \\
\hline Eu & 8.0 & 7.0 & 7.0 & 7.0 & 8.0 & 8.0 & 8.0 \\
\hline Gd & 41.0 & 36.0 & 35.0 & 33.0 & 40.0 & 41.0 & 41.0 \\
\hline Tb & 6.0 & 6.0 & 6.0 & 5.0 & 6.0 & 6.0 & 6.0 \\
\hline Dy & 32.0 & 29.0 & 28.0 & 26.0 & 32.0 & 33.0 & 32.0 \\
\hline Ho & 7.0 & 6.6 & 6.0 & 6.0 & 7.0 & 7.0 & 7.0 \\
\hline Er & 13.0 & 12.0 & 12.0 & 11.0 & 13.0 & 14.0 & 13.0 \\
\hline $\mathbf{T m}$ & 2.5 & 2.3 & 2.1 & 2.0 & 2.5 & 2.7 & 2.4 \\
\hline Yb & 15.0 & 14.0 & 14.0 & 13.0 & 15.0 & 17.0 & 15.0 \\
\hline Lu & 2.3 & 2.1 & 2.1 & 1.9 & 2.3 & 2.7 & 2.3 \\
\hline $\mathbf{U}$ & 5.9 & 5.1 & 5.1 & 4.7 & 5.1 & 5.2 & 4.7 \\
\hline Th & 49.6 & 35.1 & 36.2 & 36.1 & 42.8 & 37.5 & 44.6 \\
\hline Ta & 0.84 & 0.74 & 0.74 & 0.88 & 0.86 & 1.04 & 0.91 \\
\hline
\end{tabular}


Table.4. Comparison of average transition elements concentration (\%) in surface and buried nodules from siliceous ooze in the Central Indian Ocean Basin.

\begin{tabular}{|c|c|c|}
\hline Element & Surface nodules (a) & Buried nodules (b) \\
\hline $\mathrm{Mn}$ & 27.3 & 24.6 \\
\hline $\mathrm{Fe}$ & 5.06 & 8.08 \\
\hline $\mathrm{Co}$ & 0.11 & 0.13 \\
\hline $\mathrm{Ni}$ & 1.05 & 0.87 \\
\hline $\mathrm{Cu}$ & 1.00 & 0.87 \\
\hline $\mathrm{Mn} / \mathrm{Fe}$ & 5.40 & 3.04 \\
\hline
\end{tabular}

(a) - Jauhari (1990). $\mathrm{n}=31$

(b) - Present study. $n=13$.

Table.5. Comparison of average transition elements concentration (\%) in surface and buried nodules from red clay in the Central Indian Ocean Basin.

\begin{tabular}{|l|l|l|}
\hline Element & Surface nodules (a) & Buried nodules (b) \\
\hline $\mathrm{Mn}$ & 21.6 & 19.1 \\
\hline $\mathrm{Fe}$ & 8.39 & 9.54 \\
\hline $\mathrm{Co}$ & 0.18 & 0.19 \\
\hline $\mathrm{Ni}$ & 0.71 & 0.79 \\
\hline $\mathrm{Cu}$ & 0.53 & 0.41 \\
\hline $\mathrm{Mn} / \mathrm{Fe}$ & 2.57 & 2.00 \\
\hline
\end{tabular}

(a) - Jauhari (1990). $\mathrm{n}=31$

(b) Present study. $\mathrm{n}=7$ 


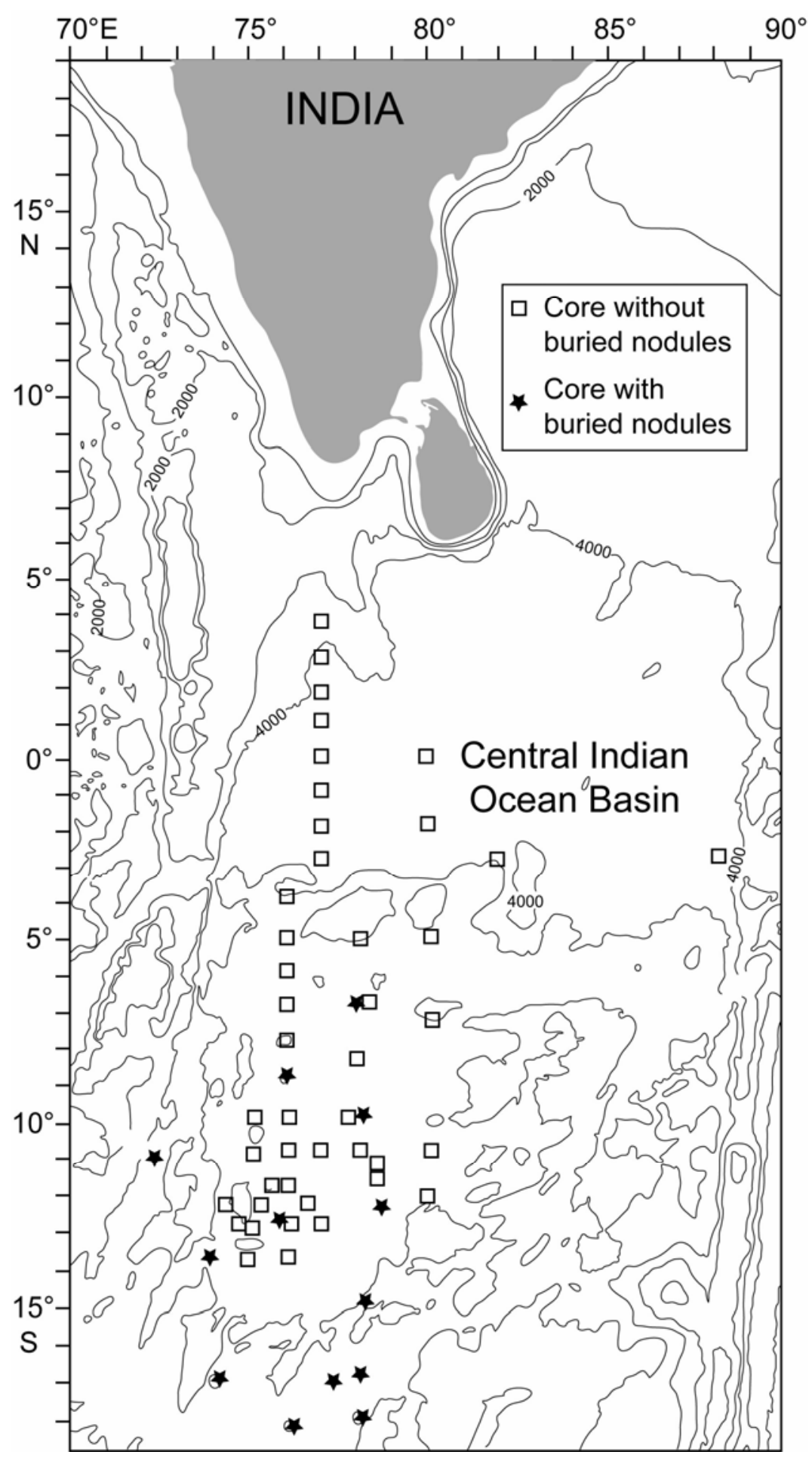

Fig.1. Location of sediment cores from the Central Indian Ocean Basin . 


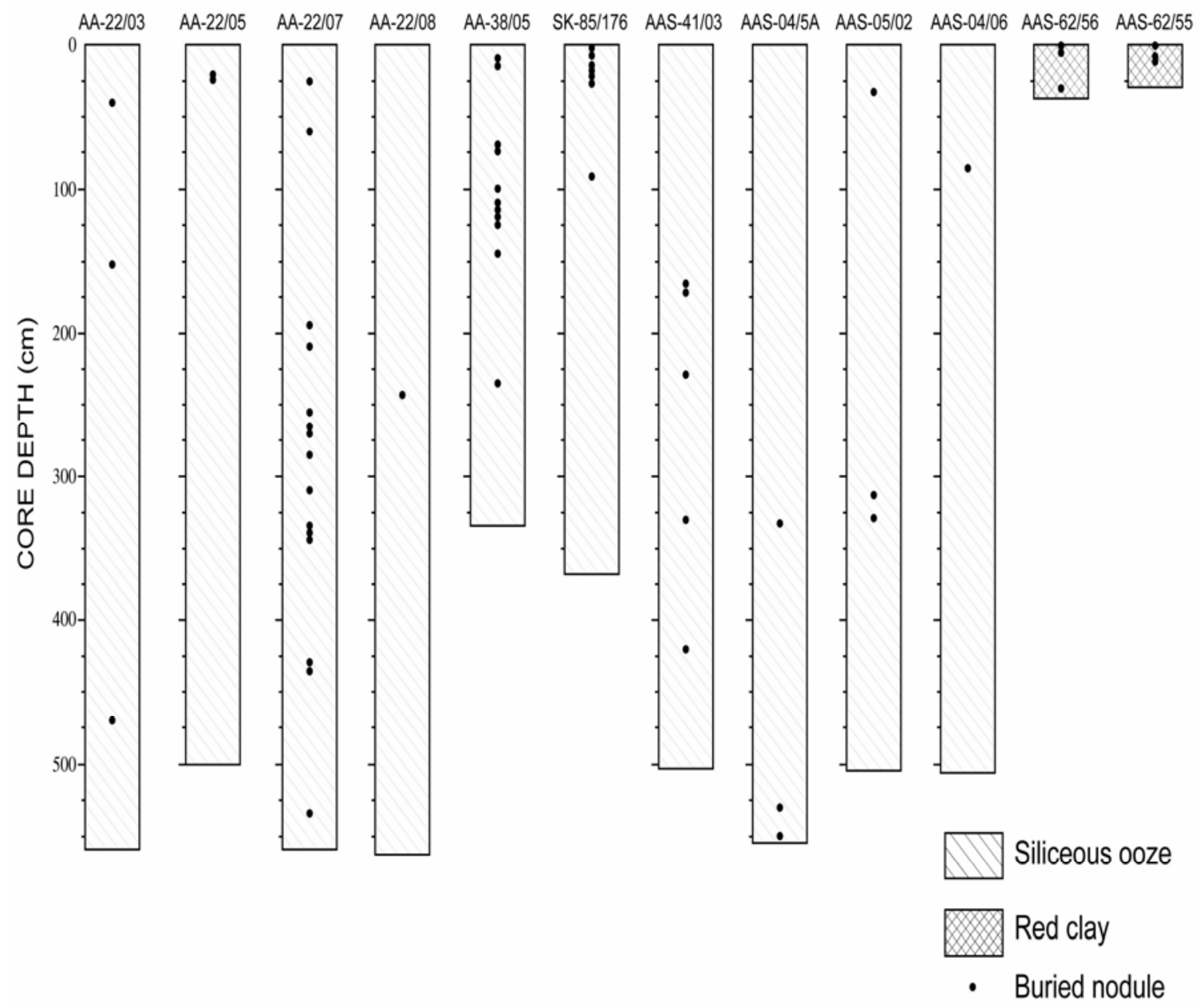

Fig.2. Distribution of buried nodules at different depths in the sediment cores. 


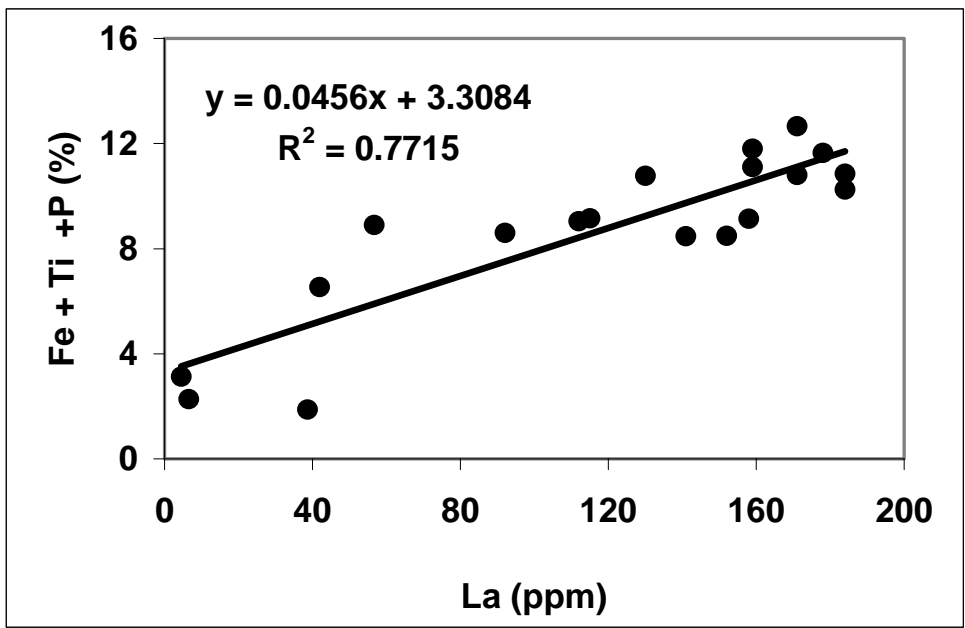

Fig.3. Scatter plot of $\mathrm{La}(\mathrm{ppm})$ and $\mathrm{Fe}+\mathrm{Ti}+\mathrm{P}(\%)$ for the buried nodules from the CIOB. 

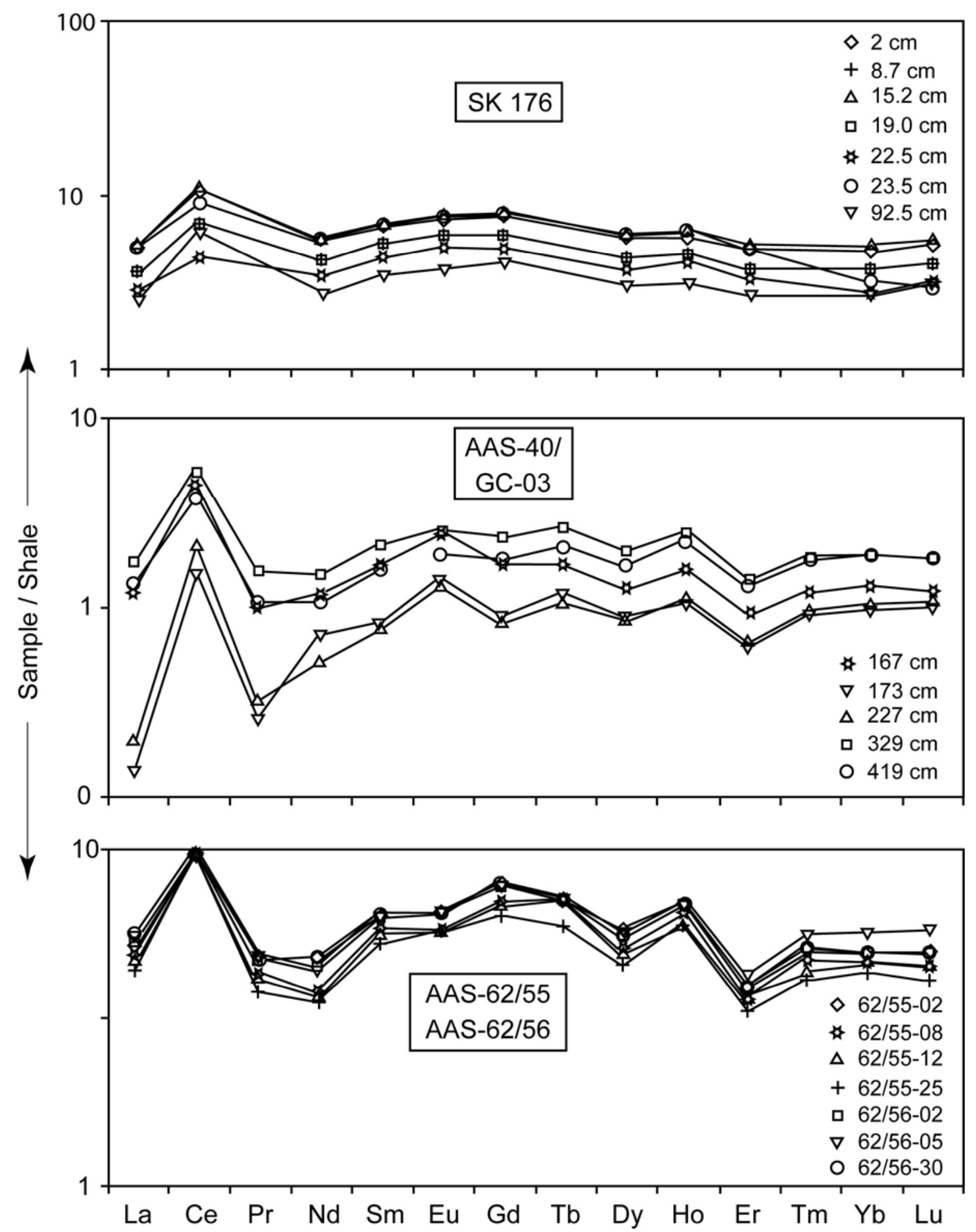

Fig.4. Shale - normalized REE pattern of buried nodules from sediment cores (SK-176), AAS-40 / GC-03, AAS-62/55 and AAS-62/56). 

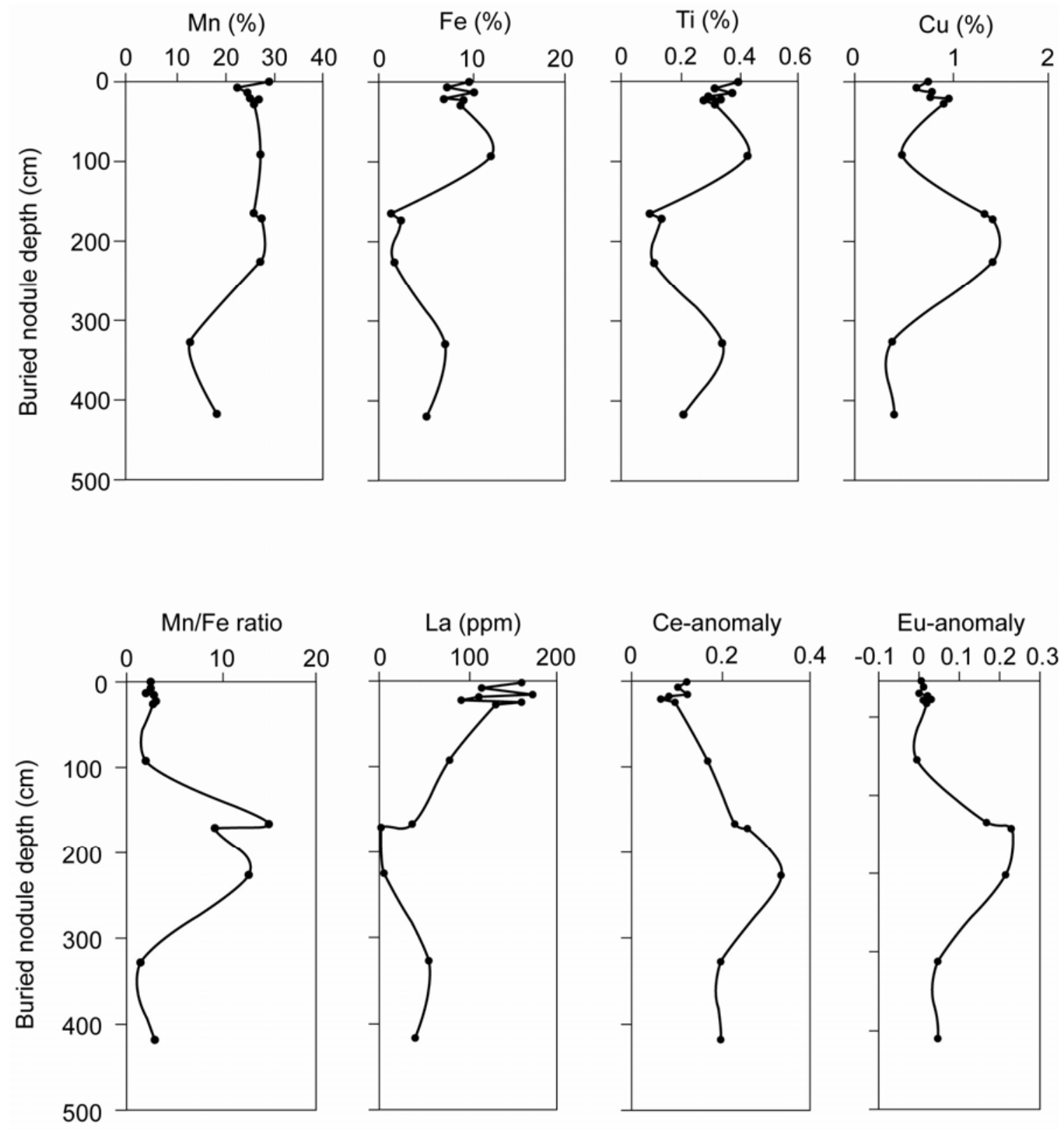

\section{Eu-anomaly}

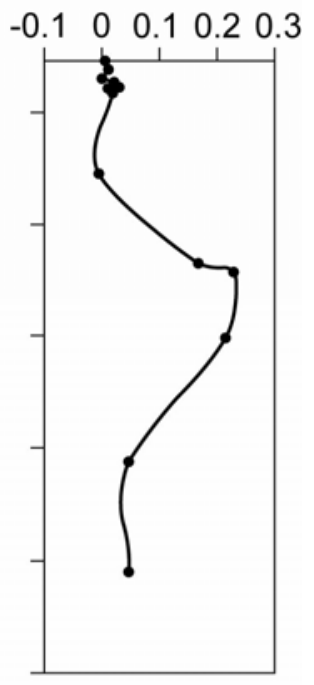

Fig.5. Distribution of Mn (\%), Fe (\%), Ti (\%), Mn./Fe ratios, La (ppm), Ce and Eu anomalies in buried nodules as a function of burial depth in siliceous ooze in the CIOB. 

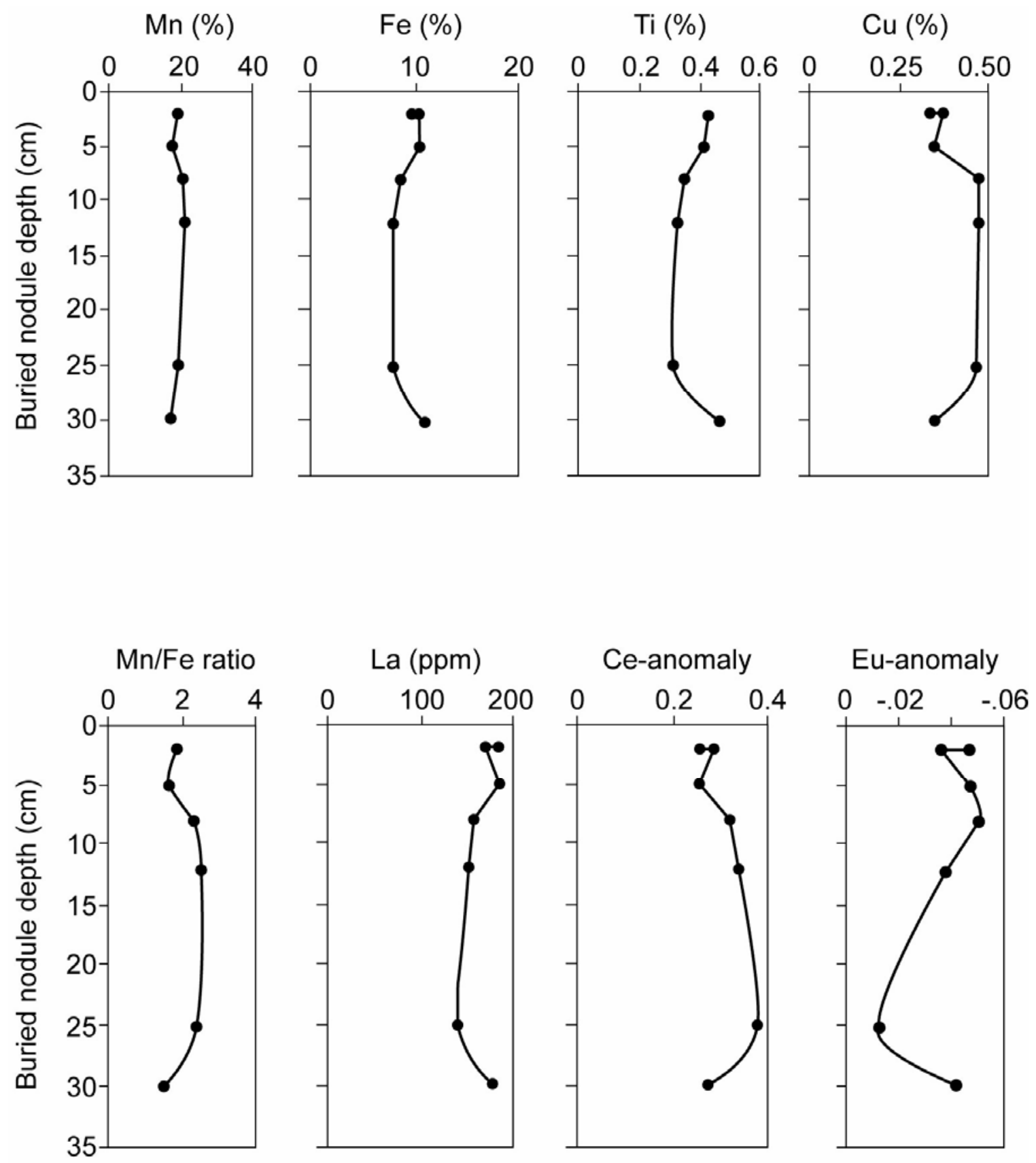

Fig. 6. Distribution of Mn (\%), Fe (\%), Ti (\%), Mn/Fe ratios, La (ppm), Ce and Eu anomalies in buried nodules as a function of burial depth in red clay in the CIOB. 